\title{
APRESENTAÇÃO
}

\section{LITERATURA EM MOVIMENTO: OS CAMINHOS DAS MIGRAÇÕES A PARTIR DE 1970}

Os debates acerca da temática da migração, elemento inerente à vida humana, tornaram-se bastante significativos a partir das grandes ondas migratórias desde o fim da Segunda Guerra Mundial. Muitos foram aqueles que se deslocaram sobre fronteiras terrestres ou marítimas: alguns partiram de países do Sul rumo a destinos no Norte do planeta, configurando um processo migratório global. Outros migraram da Europa Oriental em direção à Europa Ocidental, transformando os continentes em áreas em constante movimento. Dentre os fatores que, até os dias atuais, contribuem para a continuidade desses deslocamentos podem ser destacados aqueles que possuem viés político, como perseguições a diferentes posições nas esferas política e ideológica. Mas também devem ser mencionadas as guerras, a fome, a fuga da pobreza, as epidemias e as intolerâncias étnica e religiosa, que sempre colaboraram e continuam sendo motivação para a migração em massa de populações que buscam por melhores condições de vida. Associado a todos os motivos mencionados acima, no entanto, está também a questão econômica do local do imigrante e do local para onde a pessoa em situação desfavorável pretende se deslocar.

Em muitos países da Europa e do continente americano, o tema 'migração' se destaca no cenário literário e desperta o interesse de muitos leitores e leitoras. Ele movimenta não apenas as discussões de caráter literário e de criação textual, como também estimula debates políticos e sociológicos que permeiam as adversidades dos processos migratórios. Compreender como a questão da migração é representada, sob a perspectiva da literatura contemporânea produzida em diferentes países, surge como possibilidade de expandir os pontos de vista acerca desse assunto, lançando diferentes olhares sobre um fato tão significativo da nossa história.

O objetivo do presente dossiê consiste, portanto, em abordar a temática da migração sob o prisma de obras literárias publicadas a partir de 1970, a fim de proporcionar uma reflexão crítica no que diz respeito aos deslocamentos mais recentes que transformaram as sociedades em todo o mundo. Objetiva-se, igualmente, abranger produções que nos permitam experiências diversas com relação aos movimentos migratórios em lugares distintos do globo. Sendo assim, compõem essa publicação artigos que tratam da questão migratória e do exílio em e para diversos locais do planeta.

Caso pudéssemos transformar esse presente dossiê em um movimento, o tema do exílio e da migração se iniciaria a partir da reconstrução histórica dos movimentos em livros antigos como a Bíblia, mostrando a história humana intrinsecamente ligada a um movimento violento que surge da expulsão do paraíso e que, na literatura, encontra a sua correspondência. Após isso, seguiríamos na América do Sul, através das aproximações entre 
Bolaño e Rimbaud, tendo como perspectiva a poesia, por seu caráter de metamorfose, tal qual um movimento, no qual a escrita é a própria viagem; e também através dos impactos das viagens realizadas por Érico Veríssimo a Portugal, compiladas no livro autobiográfico Solo de Clarineta, o qual reflete seus posicionamentos críticos como um intelectual cada vez mais autônomo.

Ainda no continente americano, em uma viagem ao Norte, encontramos com as Vidas provisórias, de Edney Silvestre, a partir das considerações sobre a migração em condições precárias e invisíveis a olho nu: o estrangeiro é só mais um na massa da multidão.

Atravessando o oceano e desembarcando em terras europeias, somos apresentados às representações da temática da migração nas literaturas alemã e espanhola do século XXI, texto que constrói um panorama da temática da migração ao mostrar como os deslocamentos e os movimentos por terra e mar possibilitaram um posicionamento crítico quanto ao tema e uma abertura na escrita exofônica. Podemos constatar como o tradicional fluxo migratório se inverteu ao longo século XX nos dois países, tendo também a literatura atual com seu enfoque cada vez mais na chegada de imigrantes em condições precárias, procedentes de outros continentes.

Continuando a locomoção pelo solo alemão, entramos em contato com os deslocamentos espaciais e temporais na obra O idiota do século XXI: um divã, de Michael Kleemberg, a partir do entendimento do gênero Migrantenliteratur, conceito cunhado para designar a literatura que surge da migração e que passa pela adoção do alemão como idioma de escrita por "estrangeiros" ou, com o intuito de não marcar os escritores "estrangeiros", pessoas que migraram e que passam a produzir literatura no local em que se encontram no momento de sua produção e o fazem na língua praticada neste local. Com isso, essa escrita que atravessa e é atravessada por diferentes origens ressalta o caráter da literatura mundial, cunhado por Goethe em Conversações com Goethe, de Johann Peter Eckermann.

Ao deixar o solo alemão, deslocamo-nos por sobre fronteiras na busca pelas nascentes do rio Danúbio ao nos depararmos com o estudo sobre os ensaios de Claudio Magris e suas constantes movimentações entre espacialidades e temporalidades diversas. O enfoque no gênero espacial é importante, uma vez que, pelo fato da sua escrita se constituir em um deslocamento que vai da subjetividade para a objetividade, apresenta-se em constante movimentação, ressaltando seu caráter de viagem intelectual permeado pela paisagem (elemento conciliador entre o ser e o mundo).

Ainda em território europeu, desembarcamos, tal qual Milan Kundera, escritor tcheco exilado em solo francês, a partir do olhar das suas imagens de memórias, presentes em seus três romances escritos em francês, que parecem evocar a figuração do exílio, por meio dos deslocamentos na estrutura e organização do texto. Nesse sentido, as narrativas se movimentam e esses movimentos, planejados pelo autor, assemelham-se ao deslocar do exílio: seja do entendimento do tempo, da identidade ou das memórias.

Chegamos ao continente africano com o romance Ein Mund voll Erde, da autora alemã Stefanie Zweig. Acompanhamos os deslocamentos da protagonista Vivian e de seu pai, que partiram da Alemanha nazista rumo ao Quênia. A relação entre a pátria e o estrangeiro desponta como um movimento constante que mostra toda a complexidade dessas construções. Pai e filha surgem como representantes das diferentes conexões afetivas acionadas quando 
o indivíduo migrante recorda sua terra natal. O movimento terrestre de partida se liga, portanto, ao movimento mental de retorno.

A escolha dos roteiros dessa estrutura apresentada neste texto, por se tratar de um dossiê que tematiza os deslocamentos no século XX, corresponde ao desejo de se colocar em um movimento contrário que parte não mais da Europa como uma origem, mas como um destino. Esse entendimento vai de encontro ao contexto atual em que o continente europeu se insere e traz reflexões sobre os tensionamentos produzidos por ele: a crescente onda de xenofobia e a ascensão do pensamento nacionalista frente aos migrantes, xenofobia esta que se reflete em ondas para todos os continentes, como se pode observar muito bem em diversas áreas de conflito atuais. Mais do que nunca, esse dossiê é uma tentativa de demonstrar como a literatura se situa e reflete nessa temática, agindo como um espaço de diálogo entre diversas vozes em movimento.

Belo Horizonte, Porto Alegre e Colônia, em março de 2021,

Os organizadores.

Organizadores: Prof. Dr. Volker Jaeckel (UFMG), Gabriela Gomes de Oliveira (Universidade de Colônia), Lorena do Rosário Silva (UFMG) e Prof.Dr. Gerson Roberto Neumann (UFRGS) 
